The component structure of job satisfaction

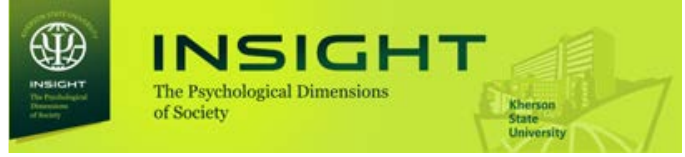
of medical workers with different working conditions

DOI: 10.32999/2663-970X/2021-6-6

Link article (Style APA): Veldbrekht, O. O., Bovdyr, O. S., \& Samkova O. M. (2021). The component structure of job satisfaction of medical workers with different working conditions. Insight: the psychological dimensions of society, 6, 73-93. DOI: 10.32999/2663-970X/2021-6-6

Link article (Style DSTU 8302: 2015): Veldbrekht, O. O., Bovdyr, O. S., Samkova, O. M. The component structure of job satisfaction of medical workers with different working conditions. Insight: the psychological dimensions of society, 2021, 6, 73-93. DOI: 10.32999/2663-970X/2021-6-6

UDC 331.101.32:616-051

\title{
The component structure of job satisfaction of medical workers with different working conditions
}

\author{
Компонентна структура задоволеності роботою \\ у медичних працівників з різними умовами праці
}

Received: September 24, 2021

Accepted: November 11, 2021

Veldbrekht Olena Oleksandrivna

Candidate of Psychological Sciences, Assistant Professor

Department of Fundamental Disciplines

HEI "Interregional Academy

of Personnel Management",

Kherson Institute, Ukraine eveldbreht@gmail.com

https://orcid.org/0000-0001-7805-0890

Bovdyr Olena Serhiivna

Candidate of Pedagogical Sciences, Associate Professor

Department of Fundamental Disciplines

HEI "Interregional Academy

of Personnel Management",

Kherson Institute, Ukraine alena20061977@ukr.net

https://orcid.org/0000-0003-2605-0754

Samkova Olesia Mykolayivna

Candidate of Psychological Sciences, Assistant Professor

Department of Fundamental Disciplines

HEI "Interregional Academy

of Personnel Management",

Kherson Institute, Ukraine

olesyasamkova8@gmail.com

https://orcid.org/0000-0001-8572-9113

\section{Вельдбрехт Олена Олександрівна} кандидат психологічних наук, доцент кафедра фундаментальних дисциплін

3ВО “Міжрегіональна академія управління персоналом",

Херсонський інститут, Україна eveldbreht@gmail.com

https://orcid.org/0000-0001-7805-0890

Бовдир Олена Сергіївна

кандидат педагогічних наук, доцент кафедра фундаментальних дисциплін

ЗВО “Міжрегіональна академія управління персоналом",

Херсонський інститут, Україна alena20061977@ukr.net

https://orcid.org/0000-0003-2605-0754

\section{Самкова Олеся Миколаївна}

кандидат психологічних наук, доцент кафедра фундаментальних дисциплін

ЗВО “Міжрегіональна академія управління персоналом",

Херсонський інститут, Україна olesyasamkova8@gmail.com

https://orcid.org/0000-0001-8572-9113 


\section{Veldbrekht Olena, \\ Bovdyr Olena, \\ Samkova Olesia}

\section{Abstract}

Nowadays, the profession is regarded as an important part of a person, which should promote his/her self-development, meet some social and existential needs. The purpose of the article is to cover the diagnostic scope of the job satisfaction questionary (JSQ) in individual counseling and monitoring of organizational space. Methods: it is presented an original tool with proven validity and reliability consisting of 38 items job components (process, conditions of implementation, results) which render individual needs in professional activity. It allows assessing the five components of satisfaction: the resourcefulness of working space, work organization, work \& life balance, the social value of work, the space of professional self-realization. Qualitative analysis of individual items demonstrates fundamental motivators, frustrated needs, and "pain points" of employees. The research has analyzed diagnostic results of 104 representatives of medical professions who have 3-35 years of experience: 55 paramedics and emergency doctors, 26 employees of a private clinic, 23 volunteers. Results of the comparative analysis of groups show that, depending on working conditions, representatives of different teams are characterized by unlike components of job satisfaction. This uniqueness is the key to developing programs for social and psychological support of employees, training activities, and organizational interventions. Group satisfaction profiles make it possible to assess the individual results of some team members objectively. This is the background against which the subjective perception of professional life unfolds; common factors can mitigate or exacerbate existing problems. Common features of the sample comprise dissatisfaction with tangible and intangible remuneration for work, awareness of the social usefulness of work, continuous training. Conclusions emphasize that different professional groups are distinguished by challenging aspects of work and their intensity. Regular monitoring of teams using the job satisfaction questionnaire makes it possible to timely respond to the relevant challenges ensuring the psychological well-being of professionals.

Keywords: motivation of professional activity, frustration, professional stress and burnout, psychological well-being, organizational counseling, organizational space.

\section{Introduction}

The idea that work should bring a person pleasure seems obvious today. However, a few decades ago, work was mainly considered a difficult and unpleasant necessity - a person's

\section{Анотація}

Сьогодні професія розглядається як важлива частина особистості, що має сприяти її саморозвитку, задовольняти ряд соціальних та екзистенційних потреб. Мета статті - розкрити діагностичні можливості опитувальника задоволеності роботою в індивідуальному консультуванні та моніторингу організаційного простору. Методи: представлено оригінальний інструмент 3 доведеною валідністю та надійністю, що складається з 38 пунктів - складових роботи (процесу, умов реалізації, результатів), які представляють потреби особистості, реалізовані у професійній діяльності. Він дозволяє оцінити п'ять компонентів задоволеності: ресурсність простору, організованість праці, баланс роботи і життя, соціальну цінність праці, простір професійної самореалізації. Якісний аналіз окремих пунктів демонструє провідні мотиватори діяльності, фрустровані потреби та “точки болю” працівників. Проаналізовано результати діагностики 104 представників медичних професій зі стажем 3-35 років: 55 фельдшерів та лікарів швидкої допомоги, 26 працівників приватної клініки, 23 волонтери. Результати порівняльного аналізування груп показали, що залежно від умов діяльності, представники різних колективів достовірно відрізняються складовими задоволеності роботою. Ця своєрідність є ключем до побудови програм соціально-психологічної підтримки працівників, навчальних заходів та організаційних втручань. Групові профілі задоволеності дають можливість об'єктивно оцінити індивідуальні результати окремих членів колективу. Це фон, на якому розгортається суб'єктивне сприйняття професійного життя; загальні чинники можуть пом'якшити або загострити наявні проблеми. Спільними особливостями вибірки виявилась незадоволеність матеріальною і нематеріальною винагородою за роботу, усвідомлення соціальної корисності праці, постійне вдосконалення кваліфікації. Висновки підкреслюють, що різні професійні групи суттєво відрізняються за переліком проблемних аспектів роботи та їх інтенсивністю. Регулярний моніторинг колективів з використанням опитувальника

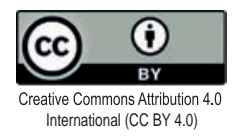


The component structure of job satisfaction of medical workers with different working conditions

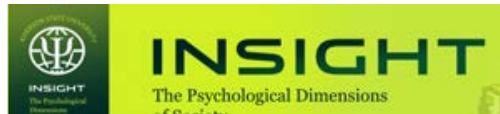

The Psych
of Society duty to society and family. Modern society focuses on other values and priorities. The profession is regarded as an essential part of an individual, which should bring joy, meet some social and spiritual needs, promote self-development. The "search for oneself" in work and the repeated change of profession throughout life turn to be widespread phenomena. The attention of leading scientists around the world is focused on the study of job expectations, its compliance with personal characteristics (Leiter \& Maslach, 2004; Maslach, 2017; Popovych \& Blynova, 2019), job satisfaction and enthusiasm (Schaufeli \& Salanova, 2011), the search for its existential meaning and significance (Steger, 2016). Organizational space is treated as a powerful external resource that provides a person with space for selfrealization and social support and influences the system of personal values and goals (Hobfoll et al., 2018).

However, this approach has a downside. An integral attribute of workused to besomeharm, loss of strength and health, abandonment of interests this fact was included in the psychological contract of employees and employers. Positive psychology has shifted the emphasis from identifying and solving existing problems to improving the strengths of an individual (including in organizational space). It is a paradox, but today's highlighted humanistic approach to work as a selfsufficient value has opened up new opportunities for the exploitation of workers and a new layer of socio-psychological problems. According to a well-known aphorism, "find a job you enjoy doing, and you will never have to work a day in your life": on the one hand, it devalues the job, and on the other - it raises unrealistic expectations about enthusiasm and satisfaction with it. In addition, it is obvious that the psychological wellbeing of an employee in the workplace is not only the need of the individual, which ensures his health and fulfilling life, but is highly beneficial to the organization which hires more loyal, proactive, and productive employees. All this makes job satisfaction a relevant realm of psychological research, as well as an object of practical interest for HR services and industrial counsellors.

Job satisfaction is a specific attitude related to professional activity and organizational scope, which задоволеності працею дозволяє вчасно реагувати на ці проблеми, забезпечуючи психологічне благополуччя фахівців.

Ключові слова: мотивація професійної діяльності, фрустрація, професійні стреси та вигорання, психологічне благополуччя, організаційне консультування, організаційний простір.

\section{Вступ}

Думка про те, що робота має приносити людині задоволення, здається сьогодні очевидною. Проте ще декілька десятиліть тому робота сприймалась переважно як важка та неприємна необхідність - обов'язок людини перед суспільством і власною родиною. Сучасне суспільство орієнтується на інші цінності та пріоритети. Професія розглядається як важлива частина особистості, що має приносити радість, задовольняти ряд соціальних та духовних потреб, сприяти саморозвитку. Поширеним явищем стає "пошук себе" в роботі та неодноразова зміна професії впродовж життя. Увага провідних вчених в усьому світі зосереджена на дослідженні очікувань від роботи, іiї відповідності характеристикам особистості (Leiter \& Maslach, 2004; Maslach, 2017; Popovych \& Blynova, 2019), задоволеності і захопленості роботою (Schaufeli \& Salanova, 2011), пошуку іiї екзистенційного значення та сенсу (Steger, 2016). Організаційний простір розглядається як могутній зовнішній ресурс, що надає людині простір для самореалізації та соціальну підтримку, а також впливає на систему особистих цінностей і цілей (Hobfoll et al., 2018).

Проте цей підхід має зворотну "темну" сторону. Раніше невід'ємним атрибутом роботи поставала певна шкідливість, втрата сил та здоров'я, відмова від власних інтересів - цей факт був закладений у психологічний контракт працівників та роботодавців. Позитивна психологія перемістила акценти 3 виявлення і вирішення наявних проблем на вдосконалення сильних сторін особистості (у тому числі в організаційному просторі). Парадоксально, але сьогоднішній підкреслено-гуманістичний підхід до праці, як самодостатньої цінності, відкрив нові можливості експлуатації працівників та новий пласт 


\section{Veldbrekht Olena, \\ Bovdyr Olena, \\ Samkova Olesia}

comprises cognitive, emotional, value, and behavioral components. On the other hand, it is an indicative common parameter rendering the outcome of professional adaptation and organizational socialization, career success, quality of life, and the psychological well-being of a person.

It is essential to realize that job satisfaction is a multicomponent phenomenon that includes a variety of external and internal components. A high salary is important to one person, and social support in a team of like-minded people to another person, one person is looking for self-esteem by solving complex problems, and another person appreciates a flexible schedule that allows one to spend time with family. Researchers name the following among subjective factors of satisfaction: the quality of personal and professional communication, the compliance of corporate goals with one's values; fair pay adequate to the level of a person's qualification and his contribution to work; social and tangible benefits; a sense of security, optimistic prospects due to affiliation; effective executive board and leadership; interesting and diverse work tasks, opportunities for advancement; proactive behavior of the employee, etc. (Kumari, 2011; Dik et al., 2013). The subjective significance of work can be beyond the person's interests combining values associated with helping other people and society, the idea of "vocation" (Steger, 2016). To diagnose job satisfaction as a multi-component unit, an original questionary has been developed and presented in this article.

The purpose of the article is to demonstrate the diagnostic scope of the job satisfaction questionary in individual counseling and monitoring of organizational space.

\section{Methodology and methods}

The research is a quasi-experiment. A comparative analysis of components of job satisfaction in three existing groups of health workers having different working conditions has been conducted. The above has allowed the authors to determine the impact of organizational space factors on the subjective perception of professional activity.

\section{Diagnostic tool}

The method of a quantitative assessment of satisfaction with career and working conditions соціально-психологічних проблем. Згідно 3 відомим афоризмом, “людина, що займається улюбленою справою, насправді не працює жодного дня у своєму житті" - це з одного боку, знецінює роботу, а з іншого - викликає нереалістичні очікування щодо захопленості і задоволеності нею. При цьому очевидно, що психологічне благополуччя працівника на робочому місці $\epsilon$ не тільки потребою індивіда, що забезпечує його здоров'я та повноцінне життя, але є надзвичайно вигідним організації, яка отримує більш лояльних, ініціативних та продуктивних співробітників. Все це робить задоволеність працею актуальною сферою психологічних досліджень, а також об'єктом практичного інтересу кадрових служб та організаційних консультантів.

Задоволеність роботою (job satisfaction) специфічний атитюд, пов'язаний з професійною діяльністю та організаційним простором, що включає в себе когнітивні, емоційні, ціннісні та поведінкові компоненти. 3 іншого боку, це показовий загальний параметр, що відображає результат професійної адаптації та організаційної соціалізації, кар'єрний успіх, якість життя та психологічне благополуччя особистості.

Треба розуміти, що задоволеність працею - це багатокомпонентний феномен, що включає різноманітні зовнішні та внутрішні складові. Для одної людини важлива висока заробітна плата, для другої - соціальна підтримка в колективі однодумців, третя шукає можливість самостверджуватись, вирішуючи складні завдання, четверта цінує вільний графік, що дозволяє проводити час з родиною. Серед суб'єктивних чинників задоволеності дослідники називають: якість спілкування на особистісному та професійному рівні, відповідність корпоративних цілей власним цінностям; справедливу оплату, адекватну рівню кваліфікації людини та їі внеску в роботу; соціальні та матеріальні пільги; відчуття безпеки, оптимістичні перспективи через приналежність до організації; ефективне керівництво та лідерство; цікавий різноманітний зміст робочих завдань, можливості кар'єрного зростання; проактивну поведінку самого співробітника, тощо (Kumari, 2011; Dik et al., 2013). Суб'єктивна значущість праці може виходити

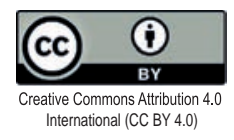


The component structure of job satisfaction of medical workers with different working conditions

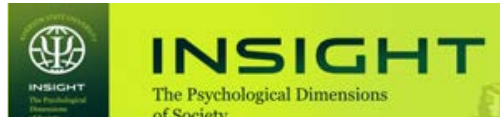

The Psych
of Society was proposed by N. Gura (2019) in the process of a comprehensive study of the factors that stipulate professional mobility or a person's affinity for the workplace. According to the data of interviews and surveys of specialists (these data laid the groundwork for the questionary), numerous reasons motivating a person to change occupation or place of work were classified. Further, in co-authorship with 0 . Veldbrekht, the method was improved: the authors revised the factor structure in different professional groups, expanded the stimulus material, and tested the tool's psychometric properties (Gura and Veldbrekht, 2021). Thus, the Job Satisfaction Questionnaire (hereinafter "JSQ") was developed; it allowed specifying an employee's attitude to his professional activity by relying on its subjective perception, emotional reactions, cognitive assessments, and value interpretation.

Themethod consists of38items-jobcomponents (its process, conditions of implementation, and outcomes), which convey the fundamental needs of an individual realized in professional activities. Respondents answer the question: "Are you satisfied with the following factors of your current professional activity?", using the Likert scale which includes options varying from "strongly dissatisfied (1 point) to "strongly satisfied" (5 points). The obtained estimates are divided into five subscales:

1. "Resourcefulness of space" renders the tangible and social motivators of work: remuneration rate, status in the team, intangible resources of the organization (social protection, corporate recreation, etc.), psychological working environment, relationships with colleagues, executives, and clients.

2. "Work organization" renders the strategic and operational aspects of management.

3. "Work-life balance" measures the impact of work on personal life, well-being, mental and physical health, a sense of stability, and security.

4. "Social value of work" assesses the satisfaction of fundamental prosocial and existential needs of an individual - awareness of one's significant contribution to other people's lives and improving the environment provides the individual with a sense of the right life way. за межі інтересів самої людини - поєднуючи сенси, пов'язані з допомогою іншим людям та суспільству, ідеєю “покликання" (Steger, 2016). Для діагностики задоволеності працею, як багатокомпонентного утворення, був розроблений оригінальний опитувальник, представлений у даній статті.

Мета публікації - продемонструвати діагностичні можливості опитувальника задоволеності роботою в індивідуальному консультуванні та в моніторингу організаційного простору.

\section{Методологія та методи}

Дослідження носило характер квазіексперименту. Проведено порівняльне аналізування компонентів задоволеності роботою в трьох реально існуючих групах медичних працівників, що відрізняються умовами праці. Це дозволило визначити вплив чинників організаційного простору на суб'єктивне сприйняття професійної діяльності.

Діагностичний інструмент

Метод кількісної оцінки задоволеності власною кар'єрою та умовами праці був запропонований Н. Гурою (2019) в процесі комплексного дослідження чинників, що зумовлюють професійну мобільність або прив'язаність людини до робочого місця. За матеріалами інтерв'ювання та опитування фахівців були класифіковані численні причини, що спонукають людину до зміни професії або місця роботи - ці дані лягли в основу змісту опитувальника. Надалі у співавторстві з О. Вельдбрехт методика була вдосконалена: переглянута факторна структура у різних професійних групах, розширений стимульний матеріал, перевірені психометричні властивості інструменту (Гура, Вельдбрехт, 2021). Таким чином був розроблений Опитувальник задоволеності роботою (далі ОЗР), що дозволив визначити ставлення працівника до своєї професійної діяльності, заснований на її суб'єктивному сприйнятті, емоційних реакціях, когнітивних оцінках, ціннісній інтерпретації.

Методика містить перелік 38 пунктів складових роботи (iї процесу, умов реалізації та результатів), які представляють провідні потреби особистості, що реалізуються в професійній діяльності. Респонденти відповідають 


\author{
Veldbrekht Olena, \\ Bovdyr Olena, \\ Samkova Olesia
}

5. "Space for professional self-realization" renders the focus of a specialist on self-realization, personal development, career advancement, as well as a certain autonomy in the course of work.

The overall index of job satisfaction is calculated as the arithmetic mean of all 38 items of the questionnaire. This parameter allows concluding about the degree of personal and professional adaptability of an individual. Analyzing the statistics of the answers to each item shows a researcher particular "pain points" - components of professional life about which an employee feels the most frustrated. These are the driving levers that influence the decision to resign: a change of employer or a more or less prolonged termination of activity (Gura, 2019). The researcher gains relevant information through two additional questions under which respondents are asked to select from the list or write in free form three or five most essential positive and negative components of the work that result in satisfaction or discomfort. This is material for content analysis - the researcher calculates the share of positive and negative points with regard to the number of participants.

The previous publications have described the process of questionnaire development in detail and substantiated its psychometric properties. The component structure of job satisfaction is confirmed in different occupational groups in which these factors justify $67.0-70.0 \%$ of the total variance of variables. The internal consistency index (Cronbach's alpha) is equal to .72-.91 for different scales and .94 for the whole method. Retest reliability is .606 ( $\mathrm{p} \leq .001)$ with a retest interval of three months and.470 ( $\mathrm{p} \leq .016)$ with an interval of sixmonths. There is observed a high discriminative capacity of the tool the option to predict the frequency and seriousness of the employee's intentions to resign under individual parameters of satisfaction. Assessments of the JSQ are closely correlated with components of professional self-fulfillment, parameters of hardiness, psychological well-being of an individual, symptoms of burnout (negative correlations), and the positive antithesis of burnout - job involvement (Gura, 2019; Gura \& Veldbrecht, 2021).

\section{Characteristics of the sample}

The research has involved 104 persons - representatives of various medical profes- на питання: “Чи задоволені ви наступними чинниками вашої поточної професійної діяльності?", використовуючи шкалу Лікерта, що включає варіанти від "абсолютно незадоволений(a)" (1 бал) до “задоволений(а) повністю" (5 балів). Отримані оцінки розподіляються за п'ятьма субшкалами:

1. Шкала "Ресурсність простору" відображає матеріальні та соціальні мотиватори праці: рівень оплати, статус в колективі, нематеріальні ресурси організації (соціальний захист, корпоративний відпочинок та ін.), психологічна атмосфера на роботі, взаємини з колегами, керівництвом та клієнтами.

2. Шкала “Організованість праці" відображає стратегічну та операційну сторони управління.

3. Шкала "Баланс роботи і життя" визначає вплив роботи на особисте життя, самопочуття, психічне і фізичне здоров'я людини; відчуття стабільності та захищеності.

4. Шкала “Соціальна цінність праці" вимірює задоволеність важливих просоціальних та екзистенційних потреб особистості - усвідомлення власного значущого внеску в життя інших людей та вдосконалення оточення, що забезпечує індивіду відчуття правильності життя.

5. Шкала "Простір професійної самореалізаціi" відображує орієнтованість фахівця на самоздійснення, особистісний розвиток, кар'єрне просування, а також певну автономність у процесі роботи.

Загальний показник задоволеності роботою розраховується як середнє арифметичне всіх 38 пунктів опитувальника. Цей параметр дозволяє зробити висновок про міру особистісно-професійної адаптованості особистості. Аналізування статистики відповідей кожного пункту розкриває досліднику індивідуальні “точки болю" - складові професійного життя, стосовно яких працівник відчуває найбільшу фрустрованість. Це рушійні важелі, котрі впливають на прийняття рішення про звільнення: зміну роботодавця або більшменш тривале припинення діяльності (Гура, 2019). Важливу інформацію досліднику надають два додаткові запитання, в яких респондентів просять обрати у списку чи написати у вільній формі три-п'ять найважливіших для них позитивних та негативних складових 
The component structure of job satisfaction of medical workers with different working conditions

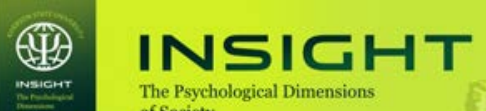

of Society sions: 55 paramedics and ambulance doctors in Kyiv, 26 employees of a private clinic, 23 volunteers with a medical degree, who worked in medical institutions in Kherson and Odesa during 20192020. The age of respondents is from 24 to 56 years (average age $38.6 \pm 11.8$ ), the experience of professional medical activity - from 3 to 35 years.

\section{Data analysis}

Processing of results includes the analysis of indicators of subscales and answers to each question of the tool. The internal consistency of points (Cronbach's alpha) varies from .76 to .89 for individual scales, .91 for the questionnaire as a whole. Parameters of the five scales and the JSQ overall index in the sample correspond to the characteristics of the normal distribution ( $\mathrm{Z}$ criterion of Kolmogorov-Smirnov ranges from .64 to 1.07, its significance ranges from .20 to.81. The comparison of average trends in the three groups has been performed using one way ANOVA with a posteriori comparison by the Bonferonni method. A comparative analysis of points under individual items has been performed using the Kruskal-Wallis test.

\section{Results}

Table 1 presents the central trends and the dispersion of estimates of subscales according to the JSQ in three occupation groups and the sample as a whole.

As you can see, the differences in the overall indicator of job satisfaction in occupational groups are not clear enough and exist only at the trend level ( $\mathrm{p}=.078$ ). However, its component structure is distinctly different depending on the working conditions. Compared to other groups, ambulance staff have the lowest level of awareness of the social significance of their work and most negatively assess job organization and opportunities for personal and professional development; nevertheless, they have more positive estimates in terms of leisure, work-life balance. At the same time, in the group of volunteers, there is a big disruption in the "work-life" scale under a relatively high prosocial orientation.

The above statistics render the frustrated needs and job satisfaction factors of medical professionals. It is relevant to HR departments of enterprises and organizations to conduct such роботи, що спричиняють задоволеність або дискомфорт. Це матеріал для контент-аналізування - дослідник підраховує частку позитивних та негативних відміток відносно кількості учасників.

У попередніх публікаціях детально описано процес розробки опитувальника, обгрунтовано його психометричні властивості. Компонентна структура задоволеності працею підтвердилась у різних професійних групах, де означені чинники пояснюють 67.070.0 \% загальної дисперсії змінних. Показник внутрішньої надійності (альфа Кронбаха) дорівнює .72-.91 для різних шкал і .94 для всієї методики. Ретестова надійність склала .606 ( $\mathrm{p} \leq .001)$ з інтервалом повторного тестування в три місяці та .470 (p $\leq .016)$ з інтервалом в шість місяців. Показана висока дискримінативна здатність інструменту - можливість за окремими параметрами задоволеності прогнозувати частоту i серйозність роздумів працівника про звільнення. Оцінки ОЗР тісно корелюють 3 компонентами професійного самоздійснення, з параметрами життєстійкості, психологічного благополуччя особистості, з симптомами професійного вигорання (негативні кореляції) та з позитивною антитезою вигорання - залученістю в роботу (Гура, 2019; Гура, Вельдбрехт, 2021).

Характеристики вибірки

У дослідженні взяли участь 104 особи - представники різних медичних професій: 55 фельдшерів та лікарів служби швидкої допомоги м. Києва, 26 працівників приватної клініки широкого профілю, 23 волонтери з медичною освітою, що працювали у закладах медичної допомоги м. Херсону та м. Одеси впродовж 2019-2020 рр. Вік опитаних - від 24 до 56 років

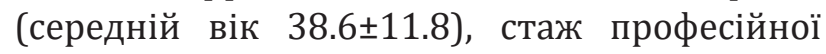
діяльності в медицині - від 3 до 35 років.

\section{Аналіз даних}

Обробка результатів містить аналізування показників субшкал та відповідей на кожне питання методики. Внутрішня узгодженість оцінок (альфа Кронбаха) склала від .76 до .89 для окремих шкал, .91 для опитувальника в цілому. Параметри п'яти шкал та загальний показник ОЗР у вибірці відповідають характеристикам нормального розподілу (критерій Z 


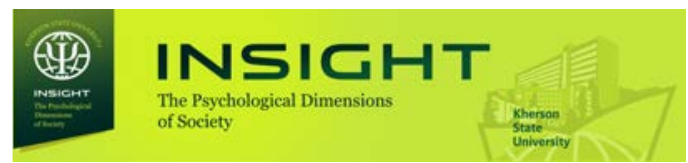

\author{
Veldbrekht Olena, \\ Bovdyr Olena, \\ Samkova Olesia
}

Table 1. Central trends and comparative analysis of indices of job satisfaction in occupational groups

Таблиця 1. Центральні тенденції та порівняльне аналізування показників задоволеності роботою в професійних групах

\begin{tabular}{|c|c|c|c|c|c|c|c|c|c|c|}
\hline \multirow[t]{2}{*}{$\begin{array}{l}\text { Scale } \\
\text { Шкала }\end{array}$} & \multicolumn{2}{|c|}{$\begin{array}{l}\text { The entire } \\
\text { sample } \\
\text { Вся вибірка } \\
\text { (N=104) }\end{array}$} & \multicolumn{2}{|c|}{$\begin{array}{c}\text { Ambulance } \\
\text { staff } \\
\text { Персонал } \\
\text { швидкої } \\
\text { допомоги } \\
\text { (N=55) }\end{array}$} & \multicolumn{2}{|c|}{$\begin{array}{c}\text { Employees of a } \\
\text { private clinic } \\
\text { Працівники } \\
\text { приватної } \\
\text { клініки } \\
(\mathrm{N}=26)\end{array}$} & \multicolumn{2}{|c|}{$\begin{array}{c}\text { Volunteers } \\
\text { of medical } \\
\text { institutions } \\
\text { Волонтери } \\
\text { медичних } \\
\text { закладів } \\
\text { (N=23) } \\
\end{array}$} & \multicolumn{2}{|c|}{ ANOVA } \\
\hline & $\mathbf{M}$ & SD & $\mathbf{M}$ & SD & $\mathbf{M}$ & SD & $\mathbf{M}$ & SD & $\mathbf{F}$ & Sig. \\
\hline $\begin{array}{l}\text { Resourcefulness of space } \\
\text { Ресурсність простору }\end{array}$ & 3.41 & .56 & 3.22 & .58 & 3.69 & .74 & 3.23 & .31 & 1.01 & .365 \\
\hline $\begin{array}{l}\text { Work organization } \\
\text { Організованість праці }\end{array}$ & 3.38 & .65 & 2.95 & .96 & 3.81 & .45 & 3.91 & .51 & 7.89 & .000 \\
\hline $\begin{array}{l}\text { Work-life balance } \\
\text { Баланс роботи і життя }\end{array}$ & 3.18 & .71 & 3.74 & .64 & 3.12 & .93 & 1.89 & .81 & 14.50 & .000 \\
\hline $\begin{array}{l}\text { Social value of work } \\
\text { Соціальна цінність } \\
\text { праці }\end{array}$ & 4.20 & .63 & 3.93 & .75 & 4.52 & .43 & 4.48 & .45 & 4.24 & .017 \\
\hline $\begin{array}{l}\text { Space of prof. } \\
\text { self-fulfillment } \\
\text { Простір проф. } \\
\text { самореалізації } \\
\end{array}$ & 3.56 & .48 & 3.13 & .61 & 4.05 & .35 & 4.01 & .22 & 3.72 & .028 \\
\hline $\begin{array}{l}\text { Overall index of } \\
\text { satisfaction } \\
\text { Заг. показник } \\
\text { задоволеності }\end{array}$ & 3.49 & .64 & 3.36 & .72 & 3.80 & .58 & 3.45 & .62 & 2.63 & .078 \\
\hline
\end{tabular}

analysis to identify the most pressing issues and develop a program of organizational changes.

The quantitative and qualitative analysis of responses to JSQ individual items are particularly informative in this context. The first step is to calculate the average estimates in the group. In parallel, the significance of the items is analyzed - the share of persons (unit fractions) who noted this item as the most negative or positive component of their job.

For example, let's consider the components of job satisfaction in a group of volunteers working in health care facilities (23 persons aged 24-29, the survey took place in January 2020 in COVID-departments). The JSQ overall index in this group is rather low (table 1). All, without exception, respondents said that they are thinking about changing activities, and two-thirds often mulled over this topic.

The analysis of responses to JSQ items (Fig. 1) shows that the main reasons for volunteering are concentrated in the factor "social value of work".

In view of the above, the opportunity to help people by their professional actions $(100.0 \%$
Колмогорова-Смирнова складає від .64 до 1.07, його значущість від .20 до .81). Порівняння середніх тенденцій у трьох групах проводилося за допомогою однофакторного дисперсійного аналізу ANOVA з апостеріорним порівнянням за методом Бонферонні. Порівняльне аналізування оцінок окремих пунктів проводився за допомогою критерію Краскела-Волліса.

\section{Результати}

У табл. 1 представлені центральні тенденції та міри розкиду оцінок субшкал за методикою ОЗР у трьох професійних групах і у вибірці в цілому.

Як бачимо, відмінності загального показника задоволеності працею в професійних групах $\epsilon$ недостатньо виразними та існують лише на рівні тенденції ( $\mathrm{p}=.078)$. Проте його компонентна структура суттєво відрізняється залежно від умов діяльності. Порівняно 3 іншими групами, персонал швидкої допомоги має найнижчий рівень усвідомлення 


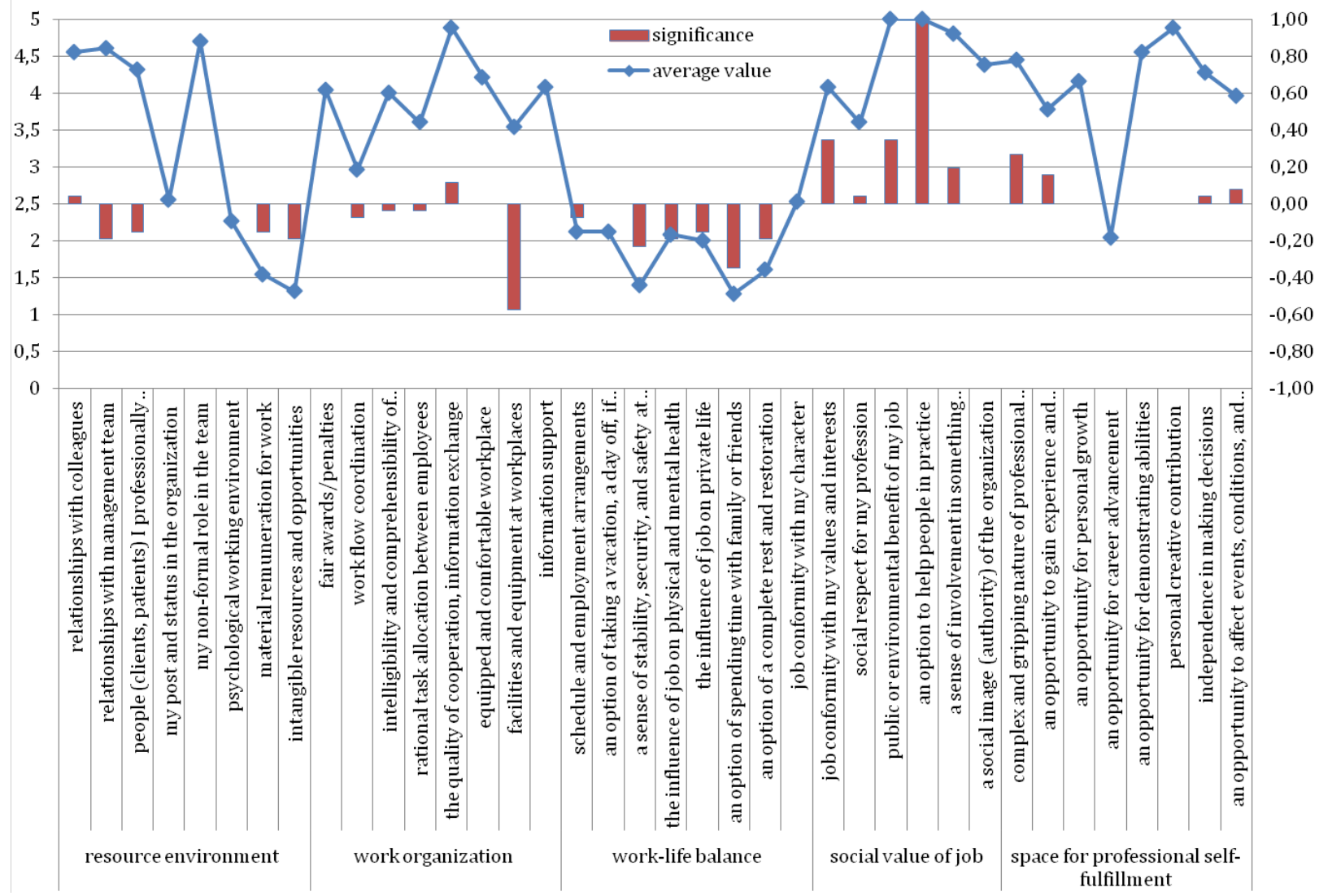

Fig. 1. Group profile of job satisfaction components of volunteers ( $\mathrm{N}=23)$.

Рис. 1. Груповий профіль складових задоволеності роботою в групі волонтерів (N=23).

of respondents indicated this reason) plays the most crucial role. It should be noted that this need is not only predominant in terms of importance but also quite satisfied - it is an efficient driving force in work. About a third of respondents marked the usefulness of their job for society and its conformity with personal values. Thus, these are the main motivators of volunteering, which should be properly realized and supported.

The negative components of volunteering vary, but respondents most often pointed to the lack of facilities and equipment for maintaining work processes. However, the average for this scale is high enough (3.5 points), $57.0 \%$ of respondents indicated that it is very stressful for them. Thus, the discomfort zone, where even minor disturbances strongly affect the employees' morale, was identified. At the same time, an employer will have little difficulty in eliminating the mentioned problem. соціальної значущості своєї роботи, найбільш негативно оцінює організованість праці та можливості власного особистісно-професійного розвитку, при цьому більш благополучний відносно можливості відпочинку, збалансованості професійного та особистого життя. У групі волонтерів, навпаки, виявлено найбільшу розбалансованість сфер "робота-життя" при відносно високій просоціальній спрямованості.

Вищеописана статистика відображує фрустровані потреби та чинники задоволеності роботою фахівців медичних професій. Таке аналізування корисно проводити кадровим службами підприємств та організацій для виявлення найбільш актуальних проблем, і розробки програми організаційних змін.

Особливо інформативним у цьому сенсі $\epsilon$ кількісне та якісне аналізування відповідей на окремі пункти ОЗР. Першим кроком 


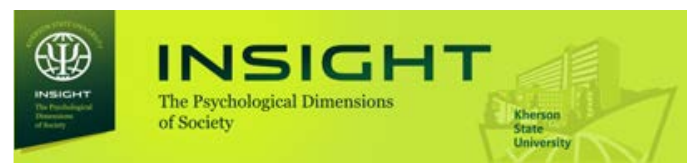

The graph in fig. 1 demonstrates a reasonably comprehensive list of "pain points" in which the outspoken dissatisfaction of employees is combined with a high subjective significance of the components. On the one hand, it concerns the insufficiency of tangible and intangible rewards; the lack of a sense of security at work. On the other hand, it concerns the adverse impact of the job on the well-being and private life of volunteers, the inability to relax and recover fully, slack in time to spend with family, or devote to non-professional hobbies. 19.0 - 38.0\% of respondents marked dissatisfaction with the above aspects, which should become "targets" of immediate psychological intervention and organizational system changes.

The authors compare the findings with the JSQ profiles of other healthcare professionals. Figure 2 conveys the statistics of emergency medical staff

\section{Veldbrekht Olena, \\ Bovdyr Olena, \\ Samkova Olesia}

$\epsilon$ розрахунок середньоарифметичних оцінок у групі. Паралельно аналізується значущість пунктів - частка осіб (в долях одиниці), що відзначили даний пункт як найбільш негативну або позитивну складову своєї праці.

Для прикладу розглянемо компоненти задоволеності працею в групі волонтерів, що працюють у закладах медичної допомоги (23 особи віком 24-29 років, опитування відбулося в січні 2020 р. в COVID-відділеннях). Загальний показник ОЗР у цій групі досить низький (табл. 1). Всі, без виключення, опитані відзначили, що замислюються про зміну діяльності, при цьому дві третини роздумували на цю тему часто.

Аналізування відповідей по пунктах ОЗР (рис. 1) показало, що основні причини займатися волонтерською діяльністю зосереджені у чиннику “соціальна цінність праці".

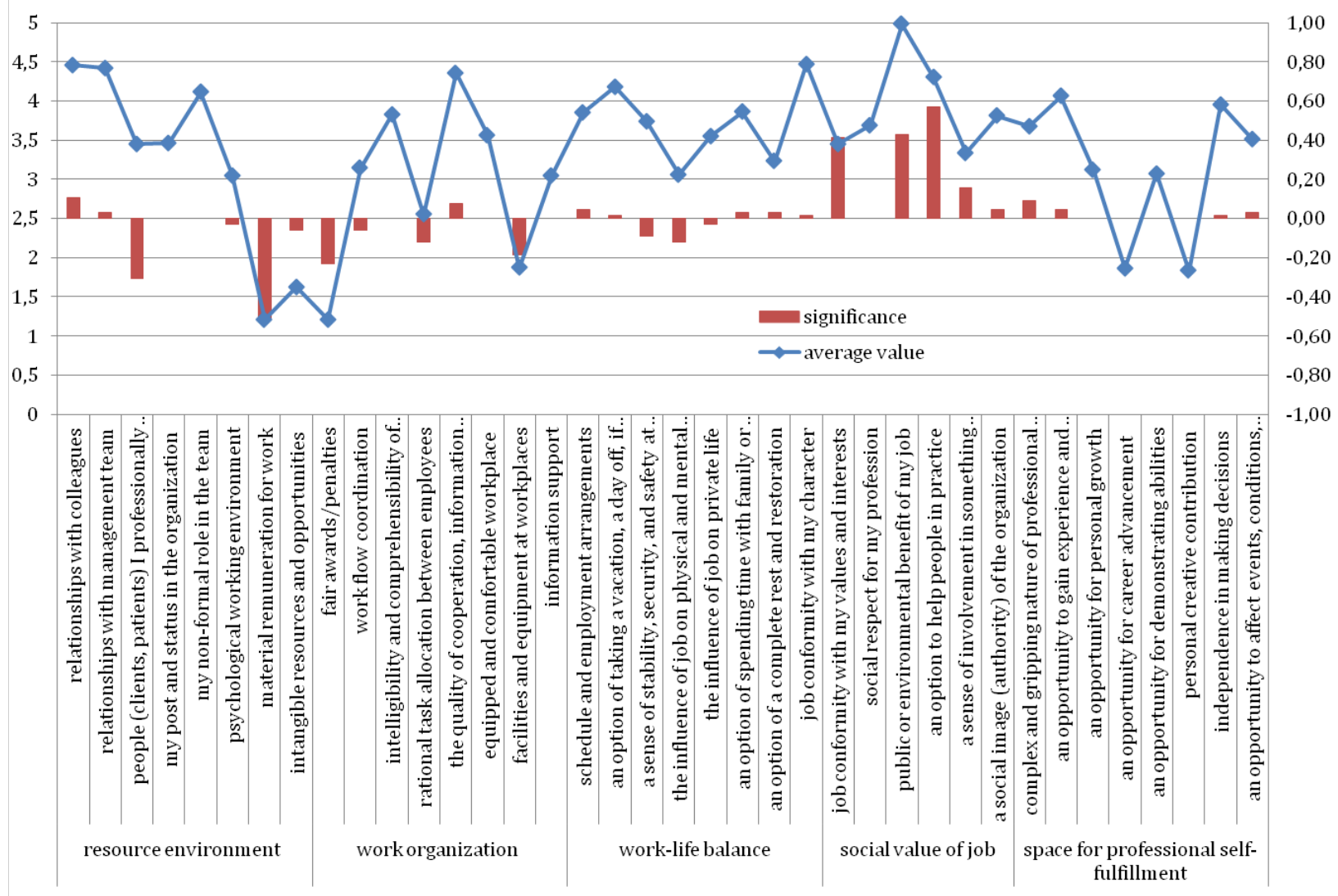

Fig. 2. Group profile of job satisfaction components of emergency medical staff ( $\mathrm{N}=55)$.

Рис. 2. Груповий профіль складових задоволеності роботою серед медичного персоналу служби швидкої допомоги (N=55). 
The component structure of job satisfaction of medical workers with different working conditions

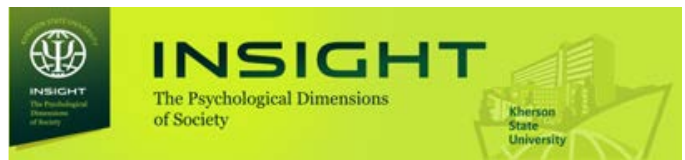

(55 people aged 25-56, the survey took place in the winter of 2020 during the exacerbation of the COVID pandemic in Ukraine). This group demonstrated the lowest overall index of job satisfaction, and the severity of frustration under some scales differs markedly from similar indicators of volunteers, who were subject to diagnostics at about the same period.

There is a sharp dissatisfaction of employees with wages accompanied by a sense of unfair appointment of remuneration and "unreasonable" distribution of job tasks. These results are likely to render the organizational crisis associated with health care reform and the initial disarrangement of advance payments to physicians during the pandemic. At the same time, the subjective significance of the social usefulness of one's job is not high enough (compared to other samples of healthcare workers), so it cannot be considered as a value and sense resource of work.

Another area of concern is related to the behavior of ambulance patients. About a third of respondents mentioned this item as the most crucial negative aspect of the job. The latter fact indicates the need for conflict management training and prevention of emotional burnout (depersonalization and cynicism) of professionals.

Consider the JSQ profile of employees of Kherson private medical clinic (26 people aged 28-55, including $73.0 \%$ of women; data were collected in the summer of 2021), which is somewhat similar to the profile of volunteers - Fig. 3. There are clear challenging areas concerning tangible and intangible rewards and work-life balance. The main reason for thinking about resignation is the insufficient level of wages, which is not compensated by intangible resources of the organization.

The peak of the positive significance of estimates is concentrated in the social usefulness of work. It seems that employees truly choose this profession by vocation - it corresponds to their character, temperament, interests, and values.

The conclusions were verified using the procedure of rank comparison of indicators - see table. 2. Numerous significant intergroup differences have been identified, which confirm the specifics of job satisfaction in the teams under study. In addition, there are common features
Серед них найголовнішу роль відіграє можливість реально допомагати людям своїми професійними діями (100.0\% респондентів вказали цю причину). Слід відзначити, що ця потреба $\epsilon$ не тільки провідною за значущістю, але й достатньо задоволеною - це діюча рушійна сила в роботі. Близько третини опитаних відзначили корисність своєї праці для суспільства, її відповідність особистим цінностям. Отже, це головні мотиватори волонтерської діяльності, що мають бути належним чином усвідомлені та підкріплені.

Негативні складові волонтерської праці різноманітні, але найбільш часто респонденти вказували на недостатню матеріально-технічну забезпеченість робочих процесів. Хоча середній показник за даним пунктом досить високий (3.5 балів), 57.0 \% опитаних вказали, що це їх сильно напружує. Отже, виявлена зона дискомфорту, в якій навіть незначні негаразди сильно впливають на моральний стан працівників. Разом з тим, усунути цю проблему для роботодавця досить нескладно.

Графік на рис. 1 демонструє досить широкий перелік “точок болю”, в яких виразна незадоволеність працівників поєднується з високою суб'єктивною значущістю складових. 3 одного боку, це недостатність матеріальної та нематеріальної винагороди; відсутність відчуття захищеності на роботі. 3 іншого боку це негативний вплив роботи на самопочуття i особисте життя волонтерів, неможливість повноцінно відпочити й відновитись, нестача часу для спілкування з родиною, позапрофесійних захоплень. Незадоволеність у цих аспектах відзначили від 19.0 до 38.0 \% респондентів. Це мають бути "мішені" негайних психологічних втручань та системних організаційних змін.

Порівняємо отримані результати 3 профілями ОЗР інших медиків. На рис. 2 відображена статистика медичного персоналу служби швидкої допомоги (55 осіб віком 25-56 років, опитування відбувалось взимку 2020 р., під час загострення пандемії COVID в Україні). Загальний показник задоволеності роботою в цій групі найнижчий, при цьому вираженість фрустрації за окремими шкалами значно відрізняється від аналогічних показників волонтерів, діагностика яких відбувалась приблизно в той самий час.

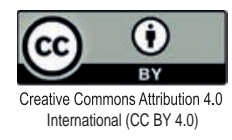




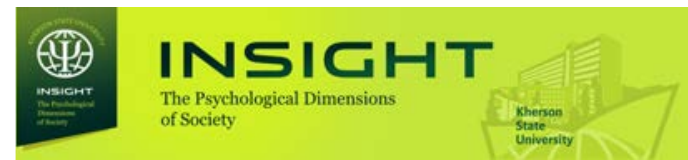

that unite the occupational groups: dissatisfaction with tangible and intangible remuneration, satisfaction with team communication, awareness of social relevance and the need for their job, continuous improvement of professional skills.

Group profiles make it possible to objectively evaluate the individual results of team members. This is the background against which the subjective perception of professional life unfolds. Common factors can mitigate or exacerbate existing problems.

Fig. 4 shows an individual profile of an experienced emergency paramedic (male, 18 years of professional experience). The overall rate of job satisfaction is 3.42 ; estimates of individual components are often polar. The specialist considers his work time-honored and useful. However, he expresses a strong desire

\section{Veldbrekht Olena, \\ Bovdyr Olena, \\ Samkova Olesia}

Ми бачимо гостру незадоволеність співробітників оплатою праці, що супроводжується відчуттям несправедливості призначення винагороди та "нерозумного" розподілу робочих функцій. Ці результати, швидше за все, відображають організаційну кризу, пов'язану 3 реформуванням системи охорони здоров'я та початковою неузгодженістю додаткових виплат медикам у період пандемії. Водночас, суб'єктивна значущість соціальної корисності власної праці $є$ недостатньо високою (порівняно з іншими вибірками медичних працівників), тому не може розглядатись як ціннісний та смисловий ресурс робочої діяльності.

Інший проблемний аспект пов'язаний 3 поведінкою пацієнтів швидкої допомоги. Близько третини респондентів відзначили

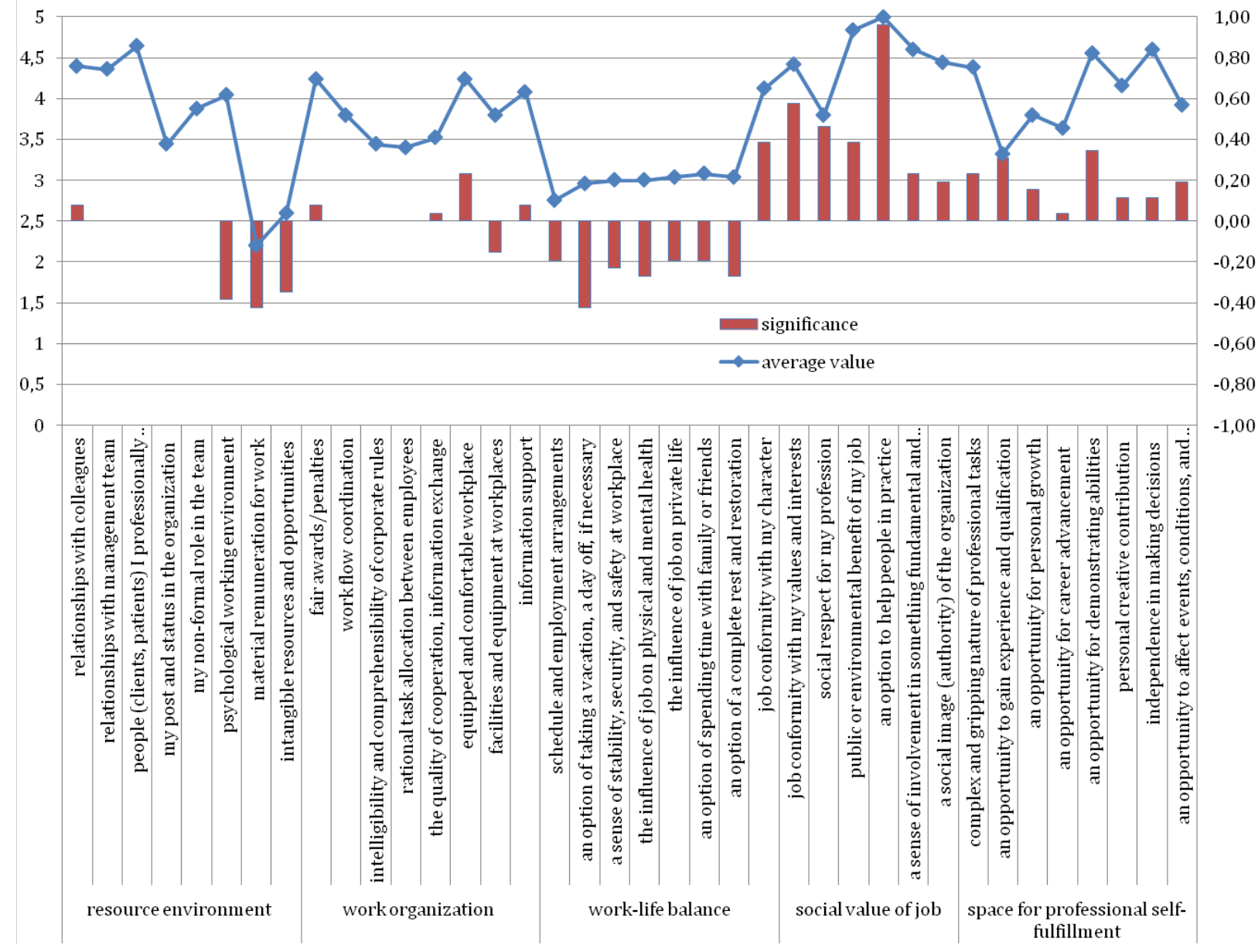

Fig. 3. Group profile of the components of job satisfaction of private clinic staff $(\mathrm{N}=26)$.

Рис. 3. Груповий профіль складових задоволеності роботою серед персоналу приватної клініки (N=26). 
The component structure of job satisfaction of medical workers with different working conditions

Table 2. Average indicators of the components of job satisfaction of emergency medical staff working in different organizational conditions

Таблиця 2. Середні показники складових задоволеності роботою медичного персоналу в різних організаційних умовах

\begin{tabular}{|c|c|c|c|c|c|}
\hline \multirow[b]{2}{*}{$\begin{array}{c}\text { Scale } \\
\text { Шкала }\end{array}$} & \multirow{2}{*}{ 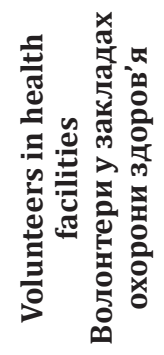 } & \multirow{2}{*}{ 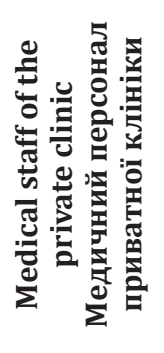 } & \multirow{2}{*}{ 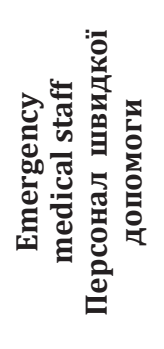 } & \multicolumn{2}{|c|}{$\begin{array}{l}\text { Kruskal Wallis Test } \\
\text { Kruskal Wallis Test }\end{array}$} \\
\hline & & & & $\begin{array}{l}\text { Chi- } \\
\text { Square }\end{array}$ & Asymp. Sig. \\
\hline 1 & 2 & 3 & 4 & 5 & 6 \\
\hline \multicolumn{6}{|c|}{$\begin{array}{l}\text { Resource environment } \\
\text { Ресурсний простір }\end{array}$} \\
\hline $\begin{array}{l}\text { relationships with colleagues } \\
\text { взаємини з колегами }\end{array}$ & 4.55 & 4.40 & 4.46 & .22 & .897 \\
\hline $\begin{array}{l}\text { relationships with management team } \\
\text { взаємини з керівництвом }\end{array}$ & 4.60 & 4.36 & 4.42 & .38 & .825 \\
\hline $\begin{array}{l}\text { people (clients, patients) } \\
\text { I professionally communicate with } \\
\text { люди (пацієнти), з якими спілкуюся по роботі }\end{array}$ & 4.31 & 4.64 & 3.45 & 6.95 & .031 \\
\hline $\begin{array}{l}\text { my post and status in the organization } \\
\text { моя посада і статус в організації }\end{array}$ & 2.55 & 3.44 & 3.46 & 6.15 & .046 \\
\hline $\begin{array}{l}\text { my non-formal role in the team } \\
\text { моя неформальна роль в колективі }\end{array}$ & 4.70 & 3.88 & 4.11 & 4.43 & .109 \\
\hline $\begin{array}{l}\text { psychological working environment } \\
\text { психологічна атмосфера на роботі }\end{array}$ & 2.26 & 4.04 & 3.05 & 11.11 & .004 \\
\hline $\begin{array}{l}\text { tangible remuneration } \\
\text { матеріальна винагорода за працю }\end{array}$ & 1.54 & 2.20 & 1.21 & 2.56 & .277 \\
\hline $\begin{array}{l}\text { intangible resources provided by the organization } \\
\text { нематеріальні ресурси, що надає організація }\end{array}$ & 1.31 & 2.60 & 1.62 & 2.76 & .252 \\
\hline \multicolumn{6}{|c|}{$\begin{array}{l}\text { Work organization } \\
\text { Організація праці }\end{array}$} \\
\hline $\begin{array}{l}\text { fair awards/penalties } \\
\text { справедливість призначення нагород/покарань }\end{array}$ & 4.04 & 4.24 & 1.21 & 23.40 & .000 \\
\hline $\begin{array}{l}\text { work flow coordination } \\
\text { налагодженість робочих процесів }\end{array}$ & 2.96 & 3.80 & 3.14 & 5.52 & .063 \\
\hline $\begin{array}{l}\text { intelligibility and comprehensibility } \\
\text { of corporate rules } \\
\text { чіткість та ясність правил, } \\
\text { встановлених у компанії }\end{array}$ & 4.00 & 3.44 & 3.83 & 1.00 & .605 \\
\hline $\begin{array}{l}\text { rational task allocation between employees } \\
\text { розумний розподіл функцій співробітників }\end{array}$ & 3.60 & 3.40 & 2.55 & 8.37 & .015 \\
\hline $\begin{array}{l}\text { the quality of cooperation, information exchange } \\
\text { якість взаємодії, обміну інформацією }\end{array}$ & 4.88 & 3.52 & 4.36 & 4.86 & .088 \\
\hline $\begin{array}{l}\text { equipped and comfortable workplace } \\
\text { облаштованість і комфортність робочого місця }\end{array}$ & 4.21 & 4.24 & 3.56 & 4.45 & .108 \\
\hline $\begin{array}{l}\text { facilities and equipment } \\
\text { for the maintenance of workflow } \\
\text { матер.-технічна забезпеченість робочих } \\
\text { процесів }\end{array}$ & 3.54 & 3.80 & 1.87 & 16.84 & .000 \\
\hline $\begin{array}{l}\text { information support } \\
\text { інформаційна підтримка }\end{array}$ & 4.08 & 4.08 & 3.05 & 6.33 & .042 \\
\hline
\end{tabular}


Continuation of table 2

Продовження таблиці 2

\begin{tabular}{|c|c|c|c|c|c|}
\hline \multicolumn{6}{|l|}{ 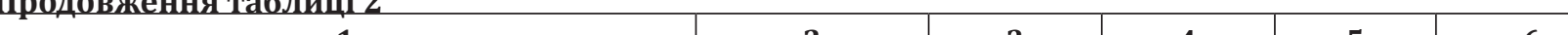 } \\
\hline 1 & 2 & 3 & 4 & 5 & 6 \\
\hline \multicolumn{6}{|c|}{$\begin{array}{l}\text { Work-life balance } \\
\text { Баланс роботи та життя }\end{array}$} \\
\hline $\begin{array}{l}\text { schedule and employment arrangements } \\
\text { розклад і режим роботи }\end{array}$ & 2.12 & 2.76 & 3.85 & 9.35 & .009 \\
\hline $\begin{array}{l}\text { an option of taking a vacation, a day off, if necessary } \\
\text { можливість брати відпустку, відгул, коли потрібно }\end{array}$ & 2.12 & 2.96 & 4.18 & 15.36 & .000 \\
\hline $\begin{array}{l}\text { a sense of stability, security, and safety at workplace } \\
\text { відчуття стабільності та безпеки на роботі }\end{array}$ & 1.39 & 3.00 & 3.74 & 22.18 & .000 \\
\hline $\begin{array}{l}\text { the influence of job on mental and physical health } \\
\text { вплив роботи на психічне та фізичне здоров'я }\end{array}$ & 2.08 & 3.00 & 3.06 & 6.17 & .046 \\
\hline $\begin{array}{l}\text { the influence of job on private life } \\
\text { вплив роботи на особисте життя }\end{array}$ & 2.00 & 3.04 & 3.55 & 7.29 & .027 \\
\hline $\begin{array}{l}\text { an option of spending time with family or friends } \\
\text { можливість проводити час з родиною або друзями }\end{array}$ & 1.28 & 3.08 & 3.86 & 17.54 & .000 \\
\hline $\begin{array}{l}\text { an option of a complete rest and restoration } \\
\text { можливість повноцінного відпочинку, } \\
\text { відновлення }\end{array}$ & 1.60 & 3.04 & 3.23 & 9.88 & .004 \\
\hline $\begin{array}{l}\text { job conformity with my character } \\
\text { відповідність роботи характеру та } \\
\text { темпераменту }\end{array}$ & 2.52 & 4.12 & 4.47 & 11.17 & .000 \\
\hline \multicolumn{6}{|c|}{$\begin{array}{c}\text { Social value of the job } \\
\text { Соціальна цінність праці }\end{array}$} \\
\hline $\begin{array}{l}\text { job conformity with my values and interests } \\
\text { відповідність роботи моїм цінностям та } \\
\text { інтересам }\end{array}$ & 4.08 & 4.42 & 3.45 & 2.81 & .245 \\
\hline $\begin{array}{l}\text { social respect for my profession } \\
\text { повага до моєї професії у суспільстві }\end{array}$ & 3.60 & 3.80 & 3.69 & .45 & .800 \\
\hline $\begin{array}{l}\text { public or environmental benefit of my job } \\
\text { корисність моєї праці для суспільства або природи }\end{array}$ & 5.00 & 4.84 & 4.98 & .24 & .887 \\
\hline $\begin{array}{l}\text { an option to help people in practice } \\
\text { можливість реально допомагати людям }\end{array}$ & 5.00 & 5.00 & 4.30 & .74 & .692 \\
\hline $\begin{array}{l}\text { a sense of involvement in something fundamental } \\
\text { and prominent } \\
\text { відчуття залученості у щось велике та важливе }\end{array}$ & 4.80 & 4.60 & 3.34 & 9.78 & .008 \\
\hline $\begin{array}{l}\text { a social image (authority) of the organization } \\
\text { соціальний імідж (авторитет) організації }\end{array}$ & 4.38 & 4.44 & 3.81 & 3.87 & .145 \\
\hline \multicolumn{6}{|c|}{$\begin{array}{c}\text { Space for professional self-fulfillment } \\
\text { Простір професійної самореалізації }\end{array}$} \\
\hline $\begin{array}{l}\text { complex and gripping nature of professional tasks } \\
\text { складність і цікавість професійних завдань }\end{array}$ & 4.44 & 4.38 & 3.68 & 4.19 & .123 \\
\hline $\begin{array}{l}\text { an opportunity to gain experience and qualification } \\
\text { можливість отримання досвіду та кваліфікації }\end{array}$ & 3.78 & 3.32 & 4.06 & 1.89 & .393 \\
\hline $\begin{array}{l}\text { an opportunity for personal growth } \\
\text { можливість саморозвитку як особистості }\end{array}$ & 4.16 & 3.80 & 3.12 & 5.51 & .064 \\
\hline $\begin{array}{l}\text { an opportunity for career advancement } \\
\text { можливість кар'єрного просування }\end{array}$ & 2.04 & 3.64 & 1.86 & 19.66 & .000 \\
\hline $\begin{array}{l}\text { an opportunity for demonstrating abilities } \\
\text { можливість проявити свої здібності }\end{array}$ & 4.55 & 4.56 & 3.07 & 7.18 & .028 \\
\hline $\begin{array}{l}\text { personal creative contribution to work } \\
\text { власний творчий внесок у роботу }\end{array}$ & 4.88 & 4.16 & 1.83 & 25.80 & .000 \\
\hline $\begin{array}{l}\text { independence in making decisions } \\
\text { самостійність у прийнятті рішень }\end{array}$ & 4.28 & 4.60 & 3.95 & 2.30 & .316 \\
\hline $\begin{array}{l}\text { an opportunity to organizational processes } \\
\text { можливість впливати на процеси в організації }\end{array}$ & 3.96 & 3.92 & 3.51 & .47 & .792 \\
\hline
\end{tabular}


to change jobs. He specified the four most negative aspects of work, of which only one coincides with the general trends of the group - low remuneration. Three individual sources of discomfort are related to basic human needs: a sense of insecurity, unsatisfactory relationships with colleagues, and a lack of free time to spend with loved ones. Extremely low indicators of life balance, uncharacteristic of this sample, attract attention. At the same time, an individual is mostly satisfied with job organization and considers it advantageous for a professional career. There is every likelihood that an employee needs an urgent vacation or a change in work schedule to restore physical and mental resources. It should be noted that the survey was conducted це як найбільш значущий негативний аспект праці. Останній факт свідчить про необхідність тренінгів конфліктної взаємодії та профілактики емоційного вигорання (деперсоналізації та цинізму) фахівців.

Розглянемо профіль ОЗР працівників приватної медичної клініки м. Херсону (26 осіб віком 28-55 років, серед яких 73.0 \% жінок; дані зібрані влітку 2021 р.), який виявився дещо схожим на профіль волонтерів - рис. 3. Ми бачимо чітко виражені проблемні зони, що стосуються матеріальної та нематеріальної нагороди, а також збалансованості сфер роботи та життя. Головною причиною роздумів про звільнення виступає недостатній рівень оплати праці, який не компенсується нематеріальними ресурсами організації.

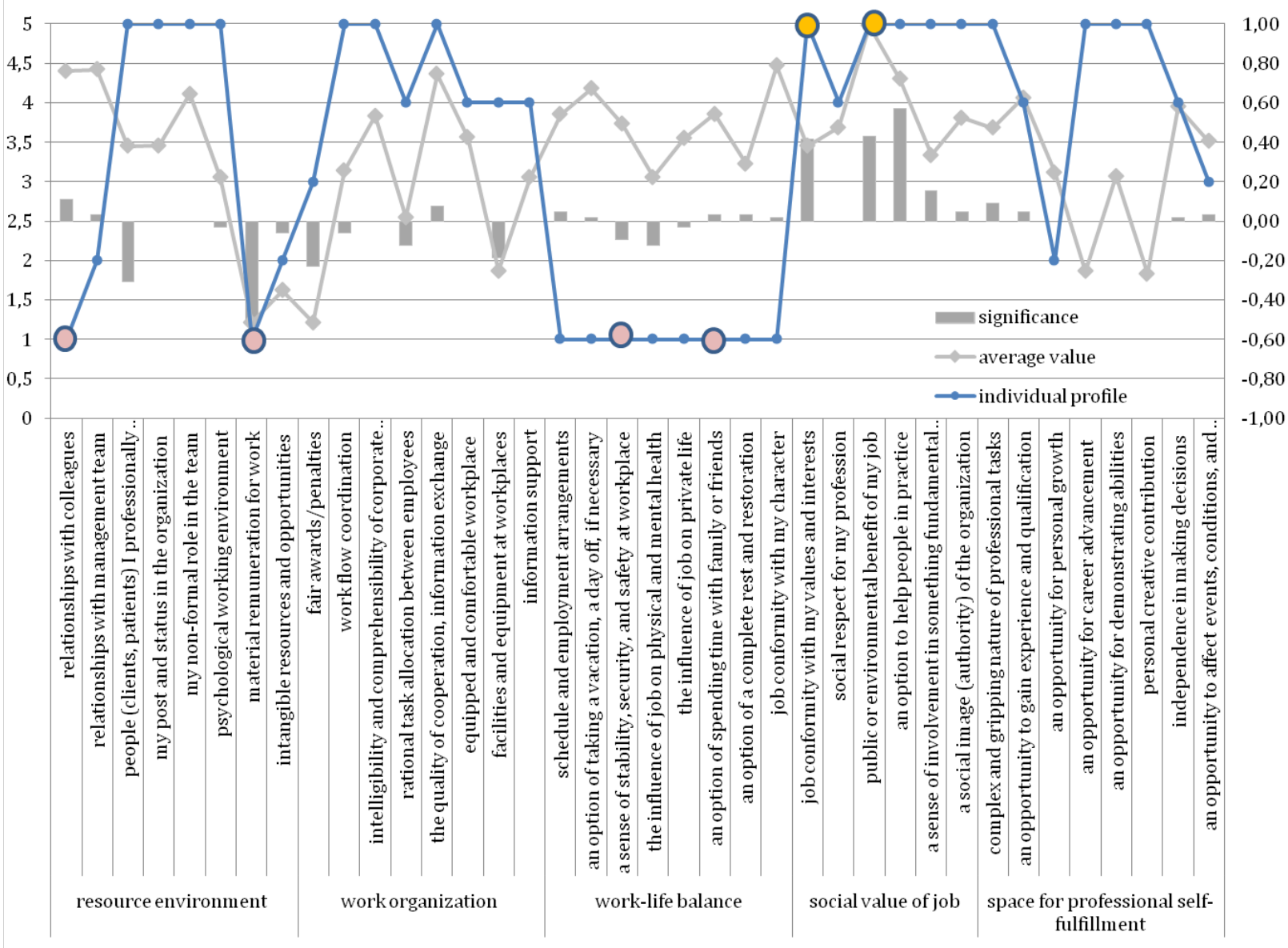

Fig. 4. Individual profile of job satisfaction against the background of the group profile of ambulance medical staff (subjectively significant parameters are marked with colored circles).

Рис. 4. Індивідуальний профіль задоволеності роботою на фоні групового профілю персоналу швидкої допомоги (кольоровими колами відмічені суб'єктивно-значущі параметри). 


\section{Veldbrekht Olena \\ Bovdyr Olena, \\ Samkova Olesia}

during another wave of the COVID-19 pandemic when the workload of emergency services was extremely high.

\section{Discussion}

Previous studies, which have accumulated data on job satisfaction in different occupational samples (medical staff, teachers, psychologists, managers, private entrepreneurs, etc.), have shown that parameters of some JSQ scales and the overall index of satisfaction vary depending on working conditions or organizational space in which activities are carried out (Glavinska et al., 2020), as well as according to job title (Gura \& Veldbrecht, 2021). This contribution has allowed specifying these differences and using them as a basis for planning psychological interventions.

A survey of health professionals has elucidated challenges associated with excessive selfsacrifice and depletion of personal resources. Due to overburden (especially of volunteers who combine the main job with free assistance), a person does not have time to relax and recover fully before the next work cycle. This stimulates protective processes aimed at saving personal resources (energy, cognitive, emotional) through psychological distancing from job. As confirmed in the study, patients are another factor of occupational stress. The classic works by Ch. Maslach explain that close social contact with aid recipients is the main cause of burnout (Maslach, 2017). These relationships are asymmetrical and unbalanced, and there is no social exchange as one person provides help and the other demands and receives it. In essence, it is the donor-recipient relationship that results in the alienation and dehumanization of employees. The obtained data confirm and supplement the conclusions of domestic scientists who have dealt with the professional stresses of Ukrainian physicians and the resources to overcome them (Pomytkina \& Ichanska, 2021); values and motives of volunteers (Koval \& Spitsyna, 2021).

From a practical point of view, the central aim of the diagnosis of job satisfaction involves preventing staff turnover, purposeful and balanced improvement of working conditions to advance psychological well-being, loyalty, and efficiency of employees. This contribution can be a part
Пік позитивної значущості оцінок розташований у зоні соціальної корисності праці. Складається враження, що працівники дійсно обирають цю роботу за покликанням - вона відповідає їх характеру, темпераменту, інтересам та цінностям.

Зроблені висновки були перевірені за допомогою процедури рангового порівняння показників - див. табл. 2. Виявлені численні достовірні міжгрупові відмінності, що підтверджують специфіку задоволеності працею в досліджених колективах. Разом з тим, існують загальні особливості, що об’єднують ці професійні групи: незадоволеність матеріальною та нематеріальною винагородою за роботу, задоволеність спілкуванням всередині колективу, усвідомлення соціальної корисності та потрібності власної праці, постійне вдосконалення професійної кваліфікації.

Групові профілі дають можливість об'єктивно оцінити індивідуально результати окремих членів колективу. Це фон, на якому розгортається суб'єктивне сприйняття професійного життя. Загальні чинники можуть пом'якшити або навпаки загострити наявні проблеми.

На рис. 4 зображений індивідуальний профіль досвідченого лікаря швидкої допомоги (чоловік, 18 років професійного стажу).

Загальний показник задоволеності роботою складає 3.42; оцінки окремих компонентів часто полярні. Фахівець вважає свою працю поважною та корисною, при цьому висловлює виражене бажання змінити роботу. Він відзначив чотири найбільш негативні аспекти роботи, серед яких лише один співпадає з загальними тенденціями групи - низький рівень оплати праці. Три індивідуальні джерела дискомфорту пов'язані з базовими людськими потребами: відчуття незахищеності, незадовільні взаємини 3 колегами та відсутність вільного часу для спілкування з близькими. Звертають на себе увагу надзвичайно низькі показники збалансованості сфер життя, нехарактерні для цієї вибірки. При цьому людина переважно задоволена організацією роботи та бачить у ній потенціал для професійної кар'єри. Швидше за все, працівник потребує термінової відпустки або зміни робочого графіку для відновлення фізичних 
The component structure of job satisfaction of medical workers with different working conditions

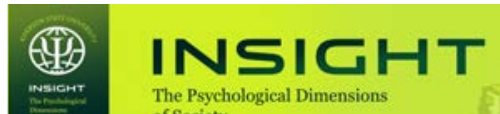

The Psych
of Society of regular monitoring in the organization or carried out as needed: when planning innovations, measures to advance corporate culture, development of programs for burnout prevention, etc. The construction of group profiles, which reflect the current problems and benefits of the organization, is the basis for diagnostic conclusions about the level of job satisfaction of a particular person. This is important from the perspective of social comparison-a person often treats the circumstances of his life, comparing them with the successes and failures of the environment.

Job satisfaction is usually associated with professional success and loyalty to the employer organization. This connection has been confirmed by numerous theoretical models and empirical studies (Kumari, 2011; Dik et al., 2013; Glavinska et al., 2020). It is logical to expect that a person with a high level of satisfaction will be more involved and interested in the results of his job performance, share corporate goals and the values of the corporate culture. Job dissatisfaction is the principal driving force behind the decision to dismiss, and in its absence - slow burnout, loss of physical and mental health. It should be kept in mind that a range of other factors (age, employment period and job experience, the situation on the labor market, family circumstances, etc.) also affect the decision to resign.

At the same time, practice shows that the higher the level of education, skills and productivity of an employee, the less job satisfaction act as a predictor oflong-term loyalty to the organization. Moreover, diagnosed job satisfaction is not a reliable predictor of such satisfaction in the future (Bezdroba \& Šunjeb, 2021). A longitudinal study of more than 21,000 participants over 40 years (Dobrow Riza, Ganzach \& Liu, 2018) found that professionals become less satisfied with a prolonged stay in one organization. In addition, satisfaction increases with age if a person changes organizations, and thus, receives higher wages.

In search for ways to solve the burnout issue, Ch. Maslach highlights the still existing prejudice aimed at "correcting people, not working situation". However, the adjustment of the organizational space to human needs is the best and most effective intervention strategy (Maslach, 2017). The Areas of Worklife Scale (AWS) outlines the areas in which та психічних ресурсів. Відмітимо, що опитування проводилось у період чергової хвилі пандемії COVID-19, коли навантаження працівників служби невідкладної допомоги було екстремально високим.

\section{Дискусія}

Попередні дослідження, в яких накопичені дані щодо проявів задоволеності роботою в різних професійних вибірках (медичного персоналу, вчителів, психологів, менеджерів, приватних підприємців, тощо), показали, що параметри окремих шкал ОЗР та загальний показник задоволеності відрізняються залежно від умов праці або організаційного простору, в яких здійснюється діяльність (Glavinska et al., 2020), а також відповідно до посадового статусу (Гура, Вельдбрехт, 2021). Наша робота дозволила деталізувати ці відмінності і використати їх як основу для планування психологічних втручань.

Опитування медичних працівників виявило негаразди, пов'язані з надмірною самовіддачею і виснаженістю персональних ресурсів. Через перевантаженість (особливо це характерно для волонтерів, які поєднують основну роботу з допомогою на безоплатній основі), людина не встигає повноцінно відпочити, відновитись до початку наступного робочого циклу. Це стимулює захисні процеси, спрямовані на економію персональних ресурсів (енергетичних, когнітивних, емоційних) шляхом психологічного дистанціювання від роботи. Іншим чинником професійного стресу, підтвердженим у дослідженні, виявились паці$\epsilon н т и . У$ класичних роботах X. Маслах було пояснено, що тісний соціальний контакт з отримувачами допомоги $\epsilon$ головною причиною вигорання (Maslach, 2017). Ці стосунки несиметричні та незбалансовані за своєю природою, в них відсутній соціальний обмін, оскільки одна людина надає допомогу, а інша - її вимагає та отримує. По суті, це стосунки донора та реципієнта, що спричиняє відстороненість та дегуманізацію працівників. Отримані дані підтверджують та доповнюють висновки вітчизняних вчених, що досліджували професійні стреси українських медиків та ресурси їх подолання (Pomytkina \& Ichanska, 2021);

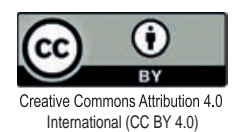




\section{Veldbrekht Olena, \\ Bovdyr Olena, \\ Samkova Olesia}

human-work compliance should be achieved: workload and requirements for the employee, ability to control space, absence of role conflicts, compliance with reward expectations, quality of social interaction and support, sense of fairness, coincidence of motives and values (Leiter \& Maslach, 2004). According to a positive approach, it is recommended to focus not just on reducing occupational stress but on promoting job involvement when changing the work context (Schaufeli \& Salanova, 2011).

On the other hand, researches by 0.0. Bogatyreva (2009) demonstrated that successful professionals do not have job satisfaction and psychological comfort. Considering the psychological factors of professional self-fulfillment, the author explains that internal conflict due to dissatisfaction with one's job stimulates the individual's need for professional and personal growth: it encourages more intensive and effective work, an activity that constructs the desired social context, and as a result, leads to career growth (Bogatyreva, 2009). The findings indicate a complex, nonlinear relationship between these phenomena and open up prospects for further research.

\section{Conclusions}

A comparative analysis of professional groups has shown that the overall level of job satisfaction is relatively equal, but its component structure depends on the working conditions. Ambulance staff have the lowest level of awareness of the social significance of their job, negatively assess its organization and opportunities for personal and professional development. At the same time, they are more positive in relation to work-life balance. The group of volunteers demonstrated the maximum dissatisfaction in terms of "work-life" with a relatively high prosocial orientation. Thus, the compilation of standardized test norms of the survey does not make practical sense without considering the specifics of professional activity and the specific conditions of its implementation. Depending on working conditions, representatives of the same occupation significantly differ in qualitative and quantitative indicators of job satisfaction. Their originality is the key to developing programs of social and psychological support for employees, training цінності та мотиви волонтерів (Koval \& Spitsyna, 2021).

3 практичної точки зору головний сенс діагностики задоволеності роботою полягає у попередженні плинності кадрів, у цілеспрямованому та виваженому поліпшенні умов праці задля збільшення психологічного благополуччя, лояльності та працездатності працівників. Ця робота може бути складовою регулярного моніторингу в організації або ж проводитись за потребою: при плануванні інновацій, заходів з поліпшення корпоративної культури, розробці програм профілактики вигорання працівників, тощо. Побудова групових профілів, що відображає актуальні проблеми та переваги організації, $є$ основою для діагностичних висновків про рівень задоволеності роботою конкретної людини. Це важливо 3 точки зору соціального порівняння - адже людина найчастіше оцінює обставини власного життя, порівнюючи їх з успіхами та негараздами оточення.

Задоволеність роботою зазвичай асоціюється з професійним успіхом та лояльністю до організації-роботодавця. Цей зв'язок підтверджений у численних теоретичних моделях та емпіричних дослідженнях (Kumari, 2011; Dik et al., 2013; Glavinska et al., 2020). Логічно очікувати, що людина з високим рівнем задоволеності буде більш залучена та зацікавлена в результатах своєї праці, поділяти цілі організації та цінності корпоративної культури. Незадоволеність роботою $є$ головною рушійною силою рішення про звільнення, а в разі його відсутності - повільного вигорання, втрати фізичного та психічного здоров'я. Слід пам'ятати, що на рішення про звільнення впливає також ряд інших чинників, таких як: вік, стаж та досвід роботи, ситуація на ринку праці, сімейні обставини та ін.

Разом з тим, практика показує, що, чим вищий рівень освіти, кваліфікації та продуктивності працівника, тим у меншій мірі задоволеність працею може служити предиктором тривалої лояльності до організації. Мало того, діагностована задоволеність роботою не $є$ надійним предиктором такої задоволеності в майбутньому (Bezdroba \& Šunjeb, 2021). Лонгітюдне дослідження, що охопило більше 
The component structure of job satisfaction of medical workers with different working conditions

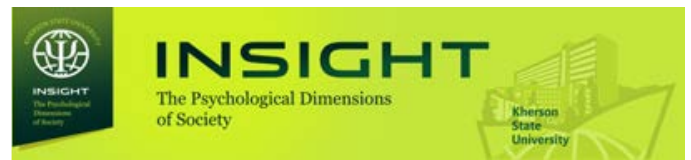

activities, and organizational interventions. The conducted research demonstrates the diagnostic capabilities of the JSQ as a tool for the implementation of psychological support programs and purposeful organizational changes.

\section{References}

Bezdroba, M., \& Šunjeb A. (2021). Transient nature of the employees' job satisfaction: The case of the IT industry in Bosnia and Herzegovina. European Research on Management and Business Economics, 27(2), 100141. https://doi.org/10.1016/j. iedeen.2020.100141

Bogatyreva, O. (2009). Lichnostnyie faktoryi professionalnoy samorealizatsii [Personal factors of professional self-realization]. Avtoref. dis. ... kand. psihol. nauk: 19.00.01. - Dissertation ... candidate of psychological sciences: 19.00.0. Moscow, 2009. http://irbis.gnpbu.ru/Aref_2009/Bogatireva_0_0_2009.pdf [in Russian]

Dik, B. J., Byrne, Z. S., \& Steger, M. F. (Eds.). (2013). Purpose and meaning in the workplace.American Psychological Association. https://doi.org/10.1037/14183-000

Dobrow Riza, S., Ganzach, Y., \& Liu, Y. (2018). Time and job satisfaction: A longitudinal study of the differential roles of age and tenure. Journal of Management, 44(7), 2558-2579. https://doi.org/10.1177/0149206315624962

Glavinska, O. D., Ovdiyenko, I. M., Brukhovetska, O. V., Chausova, T. V., \& Didenko, M. S. (2020). Professional Self-Realization as a Factor in the Psychological Well-Being of Specialists of Caring Professions. Journal of Intellectual Disability - Diagnosis and Treatment, 8(3), 548-559. https://doi.org/10.6000/2292-2598.2020.08.03.32

Gura, N. A. (2019). Zadovolenist karieroiu yak faktor kariernoho rozvytku ta sotsialno-profesiinoi mobilnosti [Career satisfaction as a career development and social and occupational mobility factor]. Orhanizatsiina psykholohiia. Ekonomichna psykholohiia - Organizational psychology. Economic psychology, 2-3(17), 35-47. https://doi.org/10.31108/2.2019.3.17.4 [in Ukrainian]

Gura, N., \& Veldbrekht, O. (2021). Opytuvalnyk zadovolenosti robotoiu: faktorna struktura ta psykhometrychni vlastyvosti [The job satisfaction questionnaire: its factor structure and psychometric characteristics]. Psykholohichnyi chasopys - Psychological journal, 7(6), 7-20. https://doi. org/10.31108/1.2021.7.6.1 [in Ukrainian]

Hobfoll, S. E., Halbesleben, J., Neveu, J.-P., \& Westman, M. (2018). Conservation of resources in the organizational context: The reality of resources and their consequences. Annual Review
21 тис. учасників впродовж 40 років (Dobrow Riza, Ganzach \& Liu, 2018), показало, що фахівці стають менш задоволені при тривалому перебуванні в одній організації. Разом з тим, задоволеність зростає з віком, якщо людина змінює організації та відповідно отримує вищу плату за працю.

Шукаючи шляхи вирішення проблеми вигорання, X. Маслах відзначає досі існуюче упередження, спрямоване на “виправлення людей, а не виправлення ситуації на роботі”. Проте, саме пристосування організаційного простору до потреб людини $є$ найкращою та найефективнішою стратегією втручання (Maslach, 2017). У моделі “сфер професійного життя" (Areas of Worklife) окреслено напрямки, в яких важливо досягнути відповідності людини та роботи: навантаження і вимоги до працівника, здатність контролювати простір, відсутність рольових конфліктів, відповідність винагороди очікуванням, якість соціальної взаємодії і підтримки, відчуття справедливості керівництва, збіг мотивів та цінностей (Leiter \& Maslach, 2004). Відповідно до позитивного підходу, при зміні робочого контексту рекомендується зосереджуватись не просто на зменшенні професійного стресу, а на сприянні залученості в роботу (Schaufeli \& Salanova, 2011).

3 іншого боку, дослідження О. О. Богатирьової (2009) показали, що у фахівців, успішних в кар'єрі, відсутні задоволеність працею i психологічний комфорт. Розглядаючи психологічні чинники професійної самореалізації, авторка пояснює, що внутрішній конфлікт через незадоволеність власною діяльністю стимулює потребу особистості в професійному та особистісному зростанні: мотивує до більш інтенсивної та ефективної праці, до активності, що конструює бажаний соціальний контекст, і в підсумку веде до кар'єрного росту (Богатырева, 2009). Отримані результати свідчать про складний, нелінійний зв'язок між цими феноменами та відкривають перспективи подальших досліджень.

\section{Висновки}

Порівняльне аналізування професійних груп показало, що загальний рівень задоволеності роботою $є$ відносно рівним, проте її компонентна 
of Organizational Psychology and Organizational Behavior, 5, 103-128. https://doi.org/10.1146/ annurev-orgpsych-032117-104640

Koval, H. V., \& Spitsyna, L. V. (2021). Empatiia yak resurs sotsialno-psykholohichnoï dopomohy $\mathrm{v}$ systemi chynnykiv volonterskoï diialnosti [Empathy as a resource of socio-psychological support in the system of factors of volunteering]. Insait: psykholohichni vymiry suspilstva: naukovyi zhurnal Insight: the psychological dimensions of society, 5, 30-45. DOI: 10.32999/2663-970X/2021-5-3

Kumari, N. (2011). Job Satisfaction of the Employees at the Workplace. European Journal of Business and Management, 3(4), 11-30. https://core.ac.uk/download/pdf/234624044.pdf

Leiter, M. P., \& Maslach, C. (2004). Areas of worklife: A structured approach to organizational predictors of job burnout. In P. L. Perrewe \& D. C. Ganster (Eds.), Research in Occupational Stress and Well-Being, 3, 91-134. Oxford: Elsevier.

Maslach, C. (2017). Finding solutions to the problem of burnout. Consulting Psychology Journal: Practice and Research, 69(2), 143-152. https://doi.org/10.1037/cpb0000090

Pomytkina L. V., \& Ichanska, O. M. (2021). Osoblyvosti kopinh-povedinky medychnykh pratsivnykiv pid chas pandemiï COVID-19 [Features of coping-behavior of medical workers during the COVID-19 pandemic]. Insait: psykholohichni vymiry suspilstva: naukovyi zhurnal - Insight: the psychological dimensions of society, 5, 148-161. DOI: $10.32999 / 2663-970 X / 2021-5-10$

Popovych, I. S., \& Blynova, O. Ye. (2019). The Structure, Variables and Interdependence of the Factors of Mental States of Expectations in Students' Academic and Professional Activities. The New Educational Review, 55 (1), 293-306. DOI: 10.15804/tner.2019.55.1.24

Schaufeli, W. B., \& Salanova, M. (2011). Work engagement: On how to better catch a slippery concept. European Journal of Work and Organizational Psychology, 20(1), 39-46. DOI: 10.1080/1359432X.2 010.515981

Steger, M. (2016). Creating Meaning and Purpose at Work. In The Wiley Blackwell Handbook of the Psychology of Positivity and Strengths-Based Approaches at Work (pp.60-81). Eds. L. Oades, M. Steger, A. Delle Fave, J. Passmore. John Wiley \& Sons. DOI: 10.1002/9781118977620.ch5 структура залежить від умов діяльності. Персонал швидкої допомоги має найнижчий рівень усвідомлення соціальної значущості своєї праці, негативно оцінює їі організованість та можливості особистісно-професійного розвитку, при цьому більш благополучний відносно збалансованості професійного та особистого життя. У групі волонтерів виявлено найбільшу розбалансованість сфер “робота-життя” при відносно високій просоціальній спрямованості. Отже, складання стандартизованих тестових норм опитувальника не має практичного сенсу без урахування специфіки професійної діяльності та конкретних умов її реалізації. Залежно від умов праці представники однієї і тієї ж самої професійної сфери значно відрізняються за якісними та кількісними ознаками задоволеності роботою. Їх своєрідність $є$ ключем до побудови програм соціальнопсихологічної підтримки працівників, навчальних заходів та організаційних втручань. Проведена робота демонструє діагностичні можливості 03Р як інструменту для впровадження програм психологічної підтримки та цілеспрямованих організаційних змін.

\section{Список використаних джерел}

Bezdroba M., Šunjeb A. Transient nature of the employees' job satisfaction: The case of the IT industry in Bosnia and Herzegovina. European Research on Management and Business Economics. 2021. Vol. 27, Is. 2, Article: 100141. DOI: 10.1016/j. iedeen.2020.100141

Богатырева 0. О. Личностные факторы профессиональной самореализации: автореф. дис. ... канд. психол. наук: 19.00.01. М., 2009. 25 c. URL: http://irbis.gnpbu.ru/Aref_2009/ Bogatireva_0_0_2009.pdf

Dik B. J., Byrne Z. S., Steger M. F. (Eds.). Purpose and meaning in the workplace. Washington, DC: American Psychological Association, 2013. DOI: 10.1037/14183-000

Dobrow Riza S., Ganzach Y., Liu Y. Time and job satisfaction: A longitudinal study of the differential roles of age and tenure. Journal of Management, 2018. Vol. 44(7). P. 2558-2579. DOI: $10.1177 / 0149206315624962$

Glavinska O. D., Ovdiyenko I. M., Brukhovetska O. V., Chausova T. V., Didenko M. S. Professional Self-Realization as a Factor in the Psychological Well-Being of Specialists of Caring Professions. Journal of Intellectual Disability - Diagnosis and Treatment.

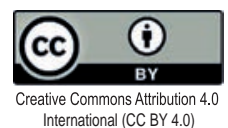


The component structure of job satisfaction of medical workers with different working conditions

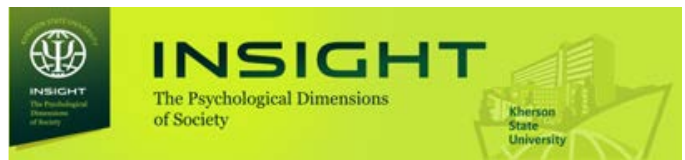

2020. Vol. 8(3). P. 548-559. DOI: $10.6000 / 2292-$ 2598.2020.08.03.32

Гура Н. А., Вельдбрехт О. О. Опитувальник задоволеності роботою: факторна структура та психометричні властивості. Психологічний часопис. 2021. Вип. 7, № 6(50). С. 7-20. DOI: 10.31108/1.2021.7.6

Гура Н. А. Задоволеність кар'єрою як фактор кар'єрного розвитку та соціально-професійної мобільності. Організаційна психологія. Економічна психологія. 2019. № 2-3. С. 35-47. DOI: $10.31108 / 2.2019 .3 .17 .4$

Hobfoll S. E., Halbesleben J., Neveu J.-P., Westman M. Conservation of Resources in the Organizational Context: The Reality of Resources and Their Consequences. Annual Review of Organizational Psychology and Organizational Behavior, 2018. Vol. 5(1). P. 103-128. DOI: 10.1146/annurevorgpsych-032117-104640

Koval H. V., Spitsyna L. V. Empathy as a resource of socio-psychological support in the system of factors of volunteering. Insight: the psychological dimensions of society, 2021. Vol. 5. P. 30-45. DOI: 10.32999/2663-970X/2021-5-3

Kumari N. Job Satisfaction of the Employees at the Workplace. European Journal of Business and Management. 2011. Vol. 3(4). P. 11-30. URL: https://core. ac.uk/download/pdf/234624044.pdf

Leiter M. P., Maslach C. Areas of worklife: A structured approach to organizational predictors of job burnout. Research in occupational stress and well being: Vol. 3. Emotional and physiological processes and positive intervention strategies / Eds. P. Perrewé, D. C. Ganster. Oxford, UK: Elsevier. P. 91-134.

Maslach C. Finding solutions to the problem of burnout. Consulting Psychology Journal: Practice and Research, 2017. Vol. 69(2). P. 143-152. DOI: $10.1037 / \mathrm{cpb} 0000090$

Pomytkina L. V., Ichanska O. M. Features of coping-behavior of medical workers during the COVID19 pandemic. Insight: the psychological dimensions of society. 2021. Vol. 5. P. 148-161. DOI: 10.32999/2663-970X/2021-5-10

Popovych I. S., Blynova O. Ye. The Structure, Variables and Interdependence of the Factors of Mental States of Expectations in Students' Academic and Professional Activities. The New Educational Review. 2019. Vol. 55(1). P. 293-306. DOI: 10.15804/tner.2019.55.1.24

Schaufeli W. B., Salanova M. Work engagement: On how to better catch a slippery concept. European Journal of Work and Organizational Psychology. 2011. Vol. 20(1). P. 39-46. DOI: 10.1080/1359432X.2010.515981

Steger M. Creating Meaning and Purpose at Work. The Wiley Blackwell Handbook of the Psychology of Positivity and Strengths-Based Approaches atWork/Eds.L.G.Oadesetal.JohnWiley\&Sons, 2016. P. 60-81. DOI: $10.1002 / 9781118977620 . c h 5$ 